\title{
The Origins of a Legal Revolution - The Early History of the European Court of Justice
}

\section{Morten RASMUSSEN}

It is widely recognised that the European Court of Justice (ECJ) has 'constitutionalized' the Treaties of Rome and today institutionally can be considered the Constitutional Court of the first pillar of the European Union (EU). ${ }^{1}$ This fact has not been kept a secret by ECJ judges and it has long been discussed by the legal literature on European law. ${ }^{2}$ The ECJ today displays several features that qualify it as a constitutional court. Originally it was endowed with the constitutional task of securing a uniform interpretation of the Treaties of Rome. To do so the ECJ developed several classic constitutional doctrines, for example concerning the relationship between European and national law or the relationship between the institutions of the polity. The ECJ also delimitated the competences of the Community and the member states and introduced fundamental rights for member state citizens. To do this the ECJ applied the methodology of a constitutional court. It eased the access of private litigants to European law through an expansive reading of article 177 (now 234) of the EEC Treaty, and it interpreted the Treaties of Rome in a teleological way applying many different interpretation methods to build its jurisprudence. This development of European law is remarkable considering that the Treaties of Rome were considered international treaties by most standards. They included no catalogue of civil and political rights, no citizenship, no clear division of power between the judicial, legislative and executive functions and no clear definition of Community competences vis-à-vis national competences. ${ }^{3}$

The decisive moment was the Van Gend en $\operatorname{Loos}^{4}$ and Costa vs. ENEL ${ }^{5}$ judgments pronounced by the ECJ in respectively 1963 and 1964. With these two judgments the ECJ revolutionised European law. By introducing the direct effect of European law and the supremacy of European law over national law, both principles to be applied inside the member states, the ECJ created a legal order of a

1. I would like to thank Karen Alter, Anne Boeger, Antonin Cohen, Billy Davies, Henning Koch, Piers Ludlow, Mikael Rask Madsen, Hjalte Rasmussen, Antoine Vauchez and Jérôme Wilson for helpful discussions of the research on which this article is based.

2. See for example F. MANCINI, The Making of a Constitution for Europe, in: Common Market Law Review, 24(1989), pp.595-614 and perhaps the most classic analysis of the early history of the ECJ, E. STEIN, Lawyers, Judges and the Making of a Transnational Constitution, in: The American Journal of International Law, 1(1981), pp.1-27.

3. M. HÖRETH, The European Court of Justice and the U.S. Supreme Court: Comparable Institutions?, in: M. GEHLER, G. BISCHOF, L. KÜNDHART, R. STEININGER (eds.), Towards a European Constitution. A Historical and Political Comparison with the United States, Böhlau Verlag, Wien-Köln-Weimar, 2005, pp.143-162, pp.143-144.

4. Aff. 26/62 N. V. Algemene Transport - en Expeditie Onderneming van Gend \& Loos v. Nederlandse Administratie der Belastingen, (1963), Recueil 1963, p.0003.

5. Aff. 6/64 Flaminio Costa v. Enel, (1964), Recueil 1964, p.1194. 
quasi-federal character and positioned itself institutionally as the Constitutional Court of the Community. At the same time the ECJ gave a very broad reading of article 177 allowing preliminary references from national courts that dealt explicitly with the junction between national and European law, even though the article only allowed the ECJ to give its interpretation of European law; not the application of the latter in the member state. The combination of direct effect and liberal access to the ECJ through national courts changed the nature of the Treaties of Rome from laying obligations on states to a catalogue of rights for national citizens. ${ }^{6}$ All these revolutionary steps were based on a legal reasoning, substantially different from traditional international law, which claimed as a consequence of the 'spirit, general scheme and wording of the treaty', the Community constituted 'a new legal order for the benefit of which the member states have limited their sovereign rights'. On this basis, the ECJ claimed the EEC Treaty to constitute a superior and autonomous legal order the powers of which were not derived from the member states. ${ }^{7}$ When the American legal scholar, Eric Stein, wrote his classic analysis of the legal revolution in 1981, he raised the crucial question of where the legal analysis underlying the Van Gend en Loos ruling came from. His answer was that the legal service of the Commission had developed the notion of the Community as a special legal order. ${ }^{8}$ By contrast, to one of the most critical voices of the ECJ, Danish law professor Hjalte Rasmussen, in his magnum opus from 1986, this notion was rather the unjustified legal invention of an activist Court. ${ }^{9}$

In this article we shall provide a new answer to Stein's question and demonstrate why Rasmussen is partly mistaken. In the first three sections, a short history of the notion of the Community as a special legal order will be presented. As it turns out the notion has two distinct, although intertwined, historical roots in respectively European federalism and the judicial development of European integration from the Treaty of Paris to the Treaties of Rome. In the final section, we shall revisit the two revolutionary judgments on the basis of new sources in order to assess the extent to which the legal revolution was an automatic consequence of the preconditions explored in the first section or whether it was of a more accidental nature.

6. R. DEHOUSSE, The European Court of Justice - The Politics of Judicial Integration, Macmillan Press LTD, London, 1998, pp.46-47.

7. E. STEIN, Lawyers ..., op.cit., pp.9-10.

8. E. STEIN, Lawyers ..., op.cit., p.24.

9. H. RASMUSSEN, On Law and Policy in the European Court of Justice, Martinus Nijhoff Publishers, Dordrect-Boston-Lancaster, 1986, pp. 11-13. 


\section{European Federalism and the Search for a European Constitution}

At the most fundamental level the historical roots of the legal revolution can be found in the federalist ideology and activities of the various transnational movements working in favour of European unification in the 1940s and 1950s. It was here that constitutional thinking on the future organisation of Europe was most ambitious, including several attempts to contemplate how a European legal order should be constructed. Moreover, a number of politicians and jurists, involved in the constitutional battles of the late 1940s and early 1950s, would later in different capacities be directly involved in or support the legal revolution of the ECJ. ${ }^{10}$

From 1947 to 1953 the European Movement and its constituent parts, among these the European Union of Federalists (UEF), the Socialist Movement for the United States of Europe (SMUSE), and the Christian Democratic, Nouvelles Equipes Internationales (NEI), made several attempts to push for the establishment of a European federation; first in the framework of the Council of Europe in 1949-50, then during the European Coal and Steel Community (ECSC) negotiations and finally in the negotiations on the European Political Community (EPC) from 1952-53. ${ }^{11}$ During this period the, often diffuse, federalist ideology inspired several concrete proposals for a federal constitution for Europe. ${ }^{12}$ Perhaps because these proposals were often drafted by jurists, and certainly due to the inspiration drawn from the American federal model, they considered a European Federal and Constitutional Court a central part of the institutional edifice of a European federation. The Council of Europe quickly disappointed European federalists and the establishment of the ECSC, which included a Court, was considered an insufficient, if important, step forward. Instead, it was the EDC Treaty and the prospect of establishing the EPC that most attracted their attention.

The first serious discussions about the nature of a federal court and a European legal order had begun before the EDC Treaty had been concluded. It was in the context of the initiative to establish the European Council of Vigilance (ECV) by the French economics professor from the University of Poitiers, Daniel Viley, that a committee of jurists was first established in 1951. The aim of the ECV was to create an alternative assembly to the Council of Europe. The task of the jurist committee was to draft a statute for a European assembly with independent political powers and financial means. The committee was chaired by Belgian

10. This section owes much to the ground breaking work by Antonin Cohen. A. COHEN, Constitutionalism without Constitution: Transnational Elites Between Political Mobilization and Legal Expertise in the Making of a Constitution for Europe (1940s-1960s), in: Law \& Social Inquiry, 32(2007), pp.109-135.

11. For general treatments focusing on the EPC see R.T. GRIFFITHS, Europe's First Constitution. The European Political Community, 1952-1954, The Federal Trust, London, 2000; D. PREDA, Sulla soglia dell'Unione. La vicenda della Communità Politica Europea (1952-1954), Editoriale Jaca Book SpA, Milano, 1993.

12. Federalism was, as pointed out by Antonin Cohen, a buzz word in the public debate in several Continental European countries that offered an alternative to Communism and past Fascist totalitarianism, but not one coherent school of thought. A. COHEN, Constitutionalism ..., op.cit., pp.123-125. 
socialist and professor in international law at the University of Liège, Fernand Dehousse and comprised secretary of the Movimento Federalista Europeo, Altiero Spinelli, and three international law professors, Hans Nawiasky (University of Munich), Piero Calamendrei (University of Florence) and Georges Scelle (University of Paris). Eventually, Viley's initiative came to nothing when the members of the Council of Europe assembly rejected the invitation of the ECV. ${ }^{13}$

In 1952 the European Movement on the initiative of its chairman, Paul Henri Spaak, reconstituted the jurist group ${ }^{14}$ as the Committee for the European Constitution. ${ }^{15}$ The task of this Committee was to prepare the ground for the planned Ad Hoc Assembly that according to article 38 of the new EDC Treaty should be given the task to draft a constitution for the EPC. Spaak now chaired the committee, with Dehousse assisting as secretary. Taking part were also four members of parliament: Lodovico Benvenuti (Italy), Pierre de Félice (France), Max Becker and Hermann Pünder (Germany). The latter three were lawyers, as were the last two members of the Committee: Cornelius Van Rij (Netherlands) and Arthur Calteux (Luxembourg). With the assistance of two prominent American legal experts Robert Bowie and Carl Friedrich ${ }^{16}$ and a research team at Harvard University, a series of comparative studies on federalism was undertaken. The fact that several members of the committee would occupy central positions in the Ad Hoc Assembly from 1952-53 meant that the reports were eventually proposed to the Constitutional Commission of the Ad Hoc Assembly. ${ }^{17}$

Before the committee closed down it published a 'Draft resolution for a European constitution' in November $1952 .{ }^{18}$ Here it was proposed to replace the ECSC ECJ with a Supreme Court constituted by a Constitutional Court (inspired by the American Supreme Court) and a Supreme Court of Appeals (modelled on the French Cour de Cassation). The government of the new Community was given the task of appointing the judges based on lists provided by the law faculties and the highest judicial organs of the member states. The appointments were for life similarly to the American Supreme Court. The Supreme Court would among other things be competent in cases of conflicts between the statute and the laws and public acts of the Community, as well as between the statute and the public law and

13. A. COHEN, Constitutionalism ..., op.cit., pp.121-125, pp.118-119.

14. With the exception of Georges Scelle.

15. The deliberations of the group has been published in D. PREDA, Per une costituzione federale dell'Europa. Lavori preparatori del Comitato di studi presieduto da P.H. Spaak 1952-1953, Cedam, Padova, 1996.

16. Carl Friedrich had been the legal advisor to Lucius Clay (military governor of occupied Germany from 1946 to 1949) and had taken part in the drafting of the constitutions of several Länder as well as that of the Federal Republic. Robert Bowie was closely involved in the negotiations on the ECSC and the EDC as director of the Policy Planning Staff of the Department of State. A. COHEN, Constitutionalism ..., op.cit., pp.124-125.

17. Spaak (chairman of the Ad Hoc Assembly), Pünder (Vice-Chairman), Benvenuti, Becker and Dehousse (members of the Constitutional commission within the Assembly).

18. This draft can be found in R.R. BOWIE, C.J. FRIEDRICH (eds.), Studies in Federalism, Little, Brown and Company, Boston/Toronto, 1954, pp.819-827. 
acts by the member states. Affected citizens, governments and Community institutions would be able to bring cases to court.

Despite the strong influence of the European Movement and the dominance of the Christian Democratic parties, the Ad Hoc Assembly chose to adopt a somewhat more cautious 'Statute of the European Community', which was marked by both federal and intergovernmental features. In this statute the future Court was to be identical with the ECSC ECJ, as had already been proposed by the governments in the EDC Treaty. While not institutionally conceived as a Constitutional Court in the way the Draft Resolution of the Committee had proposed, it was nevertheless granted constitutional features that went beyond the ECSC ECJ. Most importantly the preamble of the statute made clear that this would be a Community build on fundamental rights. According to article 45 the Court should receive appeals from plaintiffs whose rights under the Convention for the Protection of Human Rights and Fundamental Freedoms had been breached by decisions or measures of any Community institution. The rules of appeals were left open (article 41), and it was made clear that the Court would have sole jurisdiction to decide on the validity of European law (article 44). Judges would be appointed for nine years through a complicated procedure involving the member states, the European Executive Council and the Senate (article 39.1). ${ }^{19}$ After receiving the statute, the governments of the Six began an intergovernmental conference to explore how the EPC should be organised. However, as a result of the rejection of the EDC Treaty by the French National Assembly in 1954, the governments never finished these negotiations.

The fall of the EDC Treaty was clearly a devastating blow to the federalist aspirations to organise European integration efforts on the basis of federal institutions. In the immediate aftermath, it was obvious that new European initiatives would have to be organised on a more pragmatic basis and be confined mainly to economic issues. These lessons would successfully be applied in the negotiations of the Treaties of Rome. Similarly, in the field of constitutional thinking it was clear that political initiatives to provide Europe with a constitution were doomed. What was left was to develop the existing legal structure of the ECSC, including the ECJ, by gradually strengthening its constitutional nature. ${ }^{20}$ That the ECSC was the embryo of a future European Federation, and that the ECJ consequently had a constitutional role to play, was a view already promoted by centrally placed jurists such as the German official Carl Friedrich Ophüls, the ECJ General Advocate Maurice Lagrange, both of whom had negotiated the Treaty of

19. The statute can be found in R.R. BOWIE, C.J. FRIEDRICH (eds.), Studies in Federalism ..., op.cit., pp.828-855.

20. Antonin Cohen has argued that the legal debates on the constitutional nature of the Treaty of Paris and the ECJ was a legal substitute for the failed political constitution. The causal linkage implied by Cohen is not substantiated, however. I would rather consider the legal discussions, which to some extent predated the fall of the EDC Treaty and ran in parallel with the political attempts to establish a European Constitution, as yet another example of the general influence of European federalism. A. COHEN, Constitutionalism ..., op.cit., pp.125-128. 
Paris, and the ECJ Judge, Louis Delvaux. ${ }^{21}$ Lagrange formulated this view most concisely in an article published in 1954 in the Revue du droit public et de la science politique en France et à l'étranger. Here he emphasised the proto-federal nature of the ECSC and consequently the constitutional role of the ECJ. Importantly, he pointed out that ECJ jurisprudence laid the foundations for a genuinely European legal order on which a future Federal Court could base itself. ${ }^{22}$

Such thinking was shared by a loose network of pro-European jurists including for example Lagrange's former colleague from the Conseil d'Etat, who now worked as head of the legal service of the High Authority, Michel Gaudet, Walter Hallstein, professor of law and chief German negotiator during the negotiations on the Treaty of Paris, and Dehousse, who as member of the European Parliament in the mid 1960s would promote the legal revolution. ${ }^{23}$ Many of these would participate in the different national associations on European law $^{24}$ that were founded between 1953 and 1961, and in 1961 organised in the Fédération Internationale pour le Droit Européen (FIDE) ${ }^{25}$ Financed by the Commission, ${ }^{26}$ these associations and FIDE would promote European law and the ECJ both nationally and in the European context. ${ }^{27}$

Thus, while the drive for a European Federation had been dealt a blow by the fall of the EDC Treaty, the ambition to base European integration on a European constitution, including a Constitutional Court had not died. An ideology of

21. C.F. OPHÜLS, Gerichtbarkeit und Rechtsprechung im Schumanplan, in: Neue Juristische Wochenschrift, 8(1951),pp.693-697; Idem., Juristische Grundgedanken des Schumanplans, in: Neue Juristische Wochenschrift, 4(1951),pp.289-292; M. LAGRANGE, L'Ordre juridique de la CECA vu à travers la jurisprudence de sa cour de justice, in: Revue de droit et de la science politique en France et à l'étranger, 1958, pp.841-865; L. DELVAUX, La Cour de Justice de la Communauté Européenne du Charbon et de l'Acier, R. Pichon \& R. Durand-Auzias, Paris, 1956.

22. M. LAGRANGE, La Cour de Justice de la Communauté européenne du charbon et de l'acier, in: Revue du droit public et de la science politique en France et à l'étranger, 2(1954), pp.417-435, p.419: A. COHEN, Constitutionalism ..., op.cit., p.127.

23. The Historical Archive of the European Union, Florence, Archive of Fernand Dehousse, 494: La Primauté du Droit Communautaire, par Fernand Dehousse, 18 mai 1965.

24. The French 'Association Française des Juristes Européens' had already been established in 1953. The other associations were set up between 1953 and 1961; Nederlandse Vereniging voor Europees Recht, Associazione Italian dei Giuristi Europei, Association Belge pour le Droit Européen, Wissentschaftliche Gesellschaft für Europarecht and Association Luxembourgeoise des Juristes Européens.

25. Leading journals established were Rivista di diritto europeo (1961), Common Market Law Review (1964), Cahiers de droit européen (1965), Revue trimistrielle de droit Européen (1965), Europarecht (1966).

26. For a general memorandum on the links between the Commission, the national associations and FIDE consult: Historical Archive of the Commission HAC.CEAB 2. 2936, p.179, 1962-1964. Note à Monsieur les Membres du Conseil d'administration du Service Juridique des Exécutifs Européens, de M. Gaudet, R. Krawielicki, Th. Vogelaar.

27. K.J. ALTER, The European Court's Political Power, Oxford University Press, forthcoming, 2009. For the German case consult B. DAVIES, The Constitutionalisation of the European Communities: West Germany between Legal Sovereignty and European Integration 1949-1974, unpublished dissertation, King's College, 2007. 
functional constitutionalism had developed that would be at the core of the legal revolution little less than a decade later. Before returning to the importance of this ideology, we shall briefly give an impression of the legal nature of the ECSC ECJ, not through a stringent legal analysis, but by taking a look at its history from 1950 to 1956. The nature and experiences of the ECSC ECJ and the modifications it underwent in the course of the Treaties of Rome negotiations constitute the second important background to the legal revolution.

\section{The Origins of European Law}

Interestingly enough, as demonstrated more amply in Anne Boerger's contribution, ${ }^{28}$ Jean Monnet had not originally been in favour of the establishment of a strong Court in the ECSC. He feared that the establishment of a so-called 'gouvernement des juges' would fundamentally undermine the powers of the High Authority and therefore preferred some sort of international Court of Arbitration on a non permanent basis. However, under pressure from Germany and the Benelux countries it quickly became clear that a permanent Court would be central to a compromise over the institutional set up. The Court would have to deal with classic tasks of international law such as adjudicating disputes between the member states and between member states and the Hight Authority. With the somewhat belated entry into the negotiations of the then Conseiller d'Etat, Lagrange, the French changed their position and proposed in addition to model the new Court along the lines of French administrative law. The main job of the Court would consequently be to control the legality of the decisions and acts of the High Authority. This was acceptable to Monnet because it would not threaten the competences of the High Authority.

Confronting the French position were the Benelux delegations, represented by three jurisconsultes: ${ }^{29}$ Willem Riphagen (Netherlands), Christian Calmes (Luxembourg) and Fernand Muûls (Belgium), all of whom, to a varying degree wanted the Court's control of the High Authority to go beyond the judicial field. In particular the Belgian and Luxembourgian representatives insisted that the Court should have jurisdiction to censure actions by the High Authority that had negative socio-economic repercussions in a member state. The German delegation differed completely in its perception of how the Court should be conceived. The head of delegation, Hallstein, supported by the delegate from the Foreign Ministry, Ophüls, wanted to create a Federal Court similar to the new German Bundesverfassungsgericht that would ensure the development of a European Rechtsstaat. ${ }^{30}$ Over time they be-

28. A. BOEGER in this edition.

29. For a discussion of the jurisconsultes and their importance in the negotaitions see J. WILSON in this edition.

30. The law establishing in the Bundesverfassungsgericht was only passed in March 1951, which demonstrates the vision of the German key negotiators. 
lieved a Federal Court would create a European consciousness and thus play a role similar to the American Supreme Court. Therefore, the German delegation insisted on the need to develop a uniform jurisprudence with the Court holding exclusive rights to interpret the Treaty. They also wanted to offer private litigants, in this case firms and associations of firms, the option to instigate proceedings before the Court to check the legality of the decisions and acts of the High Authority. This was deemed absolutely central for two reasons. In the ECSC the High Authority would make decisions addressed directly to single firms, and given that national courts could not annul such decisions, firms would lose their legal protection without the option of an appeal to the European Court. Second, appeals from private litigants would spur the development of a uniform legal system.

The end result was probably closest to the French vision, but with important concessions made to both the Benelux and German positions. The ECJ became a mix between an administrative Court focused on the control of the legality of the decisions and actions of the High Authority, and classic international Court of Arbitration between the member states and the Community. ${ }^{31}$ Following the French line, the ECJ was in general not allowed to examine and evaluate the socio-economic consequences of ECSC policies. The sole exception was article 37, where the Benelux countries obtained the right to raise the matter with the High Authority if fundamental disturbances in the economy had been caused by the acts of the latter. If the High Authority rejected such a case, it could be appealed to the Court which then had the option to declare the rejection void.

The German request that firms be allowed to institute proceedings against decisions and acts of the High Authority had encountered tough opposition from the Benelux representatives. Muûls in particular, feared that such a system would undermine the authority of national courts and also found it unnecessary because the respective governments could bring the grievances of national firms to the High Authority and the Court. In the end, the German request fitted well with the nature of the French administrative system, i.e. the defence of the citizen against abuses of the state, and a right for firms to institute proceedings against decisions, which the High Authority had directed towards them specifically, was established (article 33). The access of private litigants to the ECJ was somewhat circumscribed, however, considering that they could not bring cases to the Court that related to the general decisions and acts of the Community. The predecessor of the famous article 177 of the EEC Treaty, article 41, which introduced a system of preliminary references in the ECSC, allowing the Court to pronounce its judgment on the validity of European law, was interestingly enough not created to satisfy German demands for a uniform interpretation of European law. Proposed instead by Lagrange, it had the sole purpose of clarifying the division of work between national courts and the new European Court. Despite the fact that the German negotiators must have had an intense interest in a more developed system of preliminary reference, they seemingly did not push the issue. Finally, the governments nominated the judges,

31. L. DELVAUX, La Cour ..., op.cit., p.19. 
who would be in office for only seven years. The independence of the judges was thus only guaranteed by the secrecy of their deliberations and the decision-making of the Court. ${ }^{32}$

How to characterise the new Court? Essentially it was an innovative mix between at least three legal traditions. Firstly, it had several features of a classic international Law, including the downside that there was no effective legal system of addressing the non-compliance of member states. Secondly, the ECJ was furnished with important tasks of administrative law. Modelled on the French Conseil d'Etat, the ECJ had to control the legality of the actions of the High Authority. Finally, the ambition of Hallstein and the German delegation to create a Federal Court similar to the American Supreme Court or the new Bundesverfassungsgericht had only met with limited success. From an institutional point of view the ECJ was clearly not a Federal or Constitutional Court. Even if certain competences that might lead to what could be termed functional constitutionalism were present, they were relatively undeveloped. Nevertheless, as Lagrange would point out in a policy memorandum in 1954 addressed to the intergovernmental conference discussing the statute of the Ad Hoc Assembly, Administrative Courts in countries in which these had a high status were also endowed with the important constitutional task of securing the rights and freedom of the citizens against abuses by the state administration. ${ }^{33}$ This was indeed the case with the ECJ in article 33, 37 and $40 .^{34}$ The constitutional features of the ECJ and the Paris Treaty were thus a mix between the tradition of administrative law of France, where Constitutional Courts in the American sense were unknown until the Fifth Republic, and the new constitutional tradition of Germany.

The jurisprudence of the ECJ before 1958 was not marked by any pronounced activism. Considering the small caseload - the Court only pronounced 27 judgments and almost all concerned the annulment of decisions under article 33 and 35 - and the weakness of article 41, this is not surprising. Nevertheless, the ECJ did gradually strengthen some of the constitutional features mentioned above. Most significantly, the ECJ made it easier for private litigants to go to Court by blurring the distinction between decisions directed towards a particular firm and general decisions and acts. The ECJ also made clear that the institutions of the Community should act within the competences granted by the Treaty of Paris. Finally, while it had been expected that the ECJ should control the High Authority, the weakness of the latter meant that the Court instead focused on protecting the Community against the transgressions of the member states. ${ }^{35}$

To conclude, the constitutional thinking of pro-European jurists such as Ophüls, Lagrange and Delvaux was not just wishful thinking, when considering the nature

32. See A. BOEGER in this edition.

33. Note sur la Cour de Justice dans la Communauté Politique Européenne, 18.3.1954, in: R. SCHULZE, T. HOEREN (eds.), Dokumente zum Europäischen Recht, Bd.2, Justiz (bis 1957), Springer, Berlin-Heidelberg-New York, 2000, pp.309-310.

34. Articles 33 and 37 are discussed above. Article 40 gave the ECJ the option to rule a pecuniary payment by the Community in cases of 'faute de service'. 
of the ECJ and its jurisprudence. At the same time it must have been clear that without reform of the Treaty of Paris there was only so much that the ECJ could do to further the constitutionality of the European construction. The legal basis and the judicial tools offered by the Treaty of Paris were simply too weak. After the collapse of the attempts by European federalists to bring about a European Constitution by political means in 1954, the question was whether the new European negotiations underway in 1956 on what would become the Treaties of Rome would offer an opportunity to strengthen the constitutional elements.

\section{The groupe de rédaction}

In the early phase of the negotiations on the Treaties of Rome, it was by no means clear how the institutional structure of the two communities would look and whether it would include a Court. After the defeat of the EDC Treaty in the French National Assembly, the governments of the Six were conscious that a new step in the field of European integration would have to focus on economic integration and were wary of unduly ambitious political schemes. This was reflected in the Spaak Report, which said relatively little on the institutional aspects of the project. ${ }^{36}$ It was also made clear by the French head of the delegation, Maurice Faure, to his colleagues shortly after the Venice conference in May 1956. Even if Faure underlined that he personally did not share the reticence of his compatriot, the bottom line was that France could not support a connection between the ECSC assembly and court, and the two projected Communities due to the widespread scepticism with regard to supranational institutions in the French National Assembly. ${ }^{37}$ France was confronted by five governments that to a varying degree whished to maintain a minimum of political coherence amongst the various efforts of European integration and considered the institutional infrastructure as an important way to do this. The delegations of the five were dominated by pro-Europeans; for example Carl Friedrich Ophüls, Jean-Charles Snoy, Lambert Schaus, Lodovico Benvenuti (heads of delegation) and Spaak (Belgian Foreign Minister), all of whom had participated in one or more of the intergovernmental negotiations on the ECSC, the EDC and the EPC during the 1950s.

In the end, the intergovernmental conference held at the castle of Val Duchesse outside Brussels did lead to a substantially different institutional set up for the EEC

35. C. PENERA, The Beginnings of the Court of Justice and its Role as a driving Force in European Integration, in: Journal of European Integration History, (1)1995, pp.111-127, here: pp.118-122 and H. RASMUSSEN, On Law and Policy ..., op.cit., pp.208-213.

36. Spaak-Bericht, 21.4.1956 in: R. SCHULZE, T. HOEREN (eds.), Dokumente ..., op.cit., pp.354-356.

37. A. BOEGER, The Background of the Institutional Set Up of the European Court of Justice - Revisiting the negotiations on the ECSC and the EEC, unpublished paper presented at the Conference on the Historical Roots of European Legal Integration, Copenhagen University, October 2007. 
and Euratom, than that established for the ECSC. Most importantly, the powers of the Council were greatly strengthened vis-à-vis what would now be termed the Commission. France eventually accepted one Assembly and ECJ to be shared by all three Communities but on the condition that the powers of these two institutions were not strengthened.

The early negotiations in the Spaak Committee had envisaged a common Court for all three communities to preserve the legal unity of the integration efforts, but found that a technical court with specialised chambers might be enough. This conclusion entered the report. Not all parties accepted the idea of preserving the legal unity of the three communities and using the ECJ as a common Court, however. In Germany, the Ministry of Economics wanted to remove the ECJ and the Assembly from the institutional edifice. The Foreign ministry rejected this view, however, and argued that the ECJ was indispensable as a stabiliser of the Communities. The greatest opposition to the ECJ unsurprisingly came from the French delegation. In a note submitted to the head of delegations on 11 September 1956, Conseiller politique of the Foreign Minister George Vedel proposed to remove the court completely. In his view most legal cases in the new Communities would be technical in nature and had better be submitted to a Court of Arbitrage constituted by technical experts. He admitted that there would be legal cases of an institutional nature but he felt certain that such cases would be very few in number and that it was consequently unnecessary to establish a real Court. Instead a permanent secretariat combined with an ad hoc appointment of judges would suffice. The lack of consensus on the destiny of the ECJ meant that it was removed from the agenda of the meeting of the head of delegations in October $1956 .{ }^{38}$

After the meeting between German Chancellor Konrad Adenauer and French Prime Minister Guy Mollet in November 1956, disagreement on the institutional set up was overtaken by the general Franco-German agreement to bring the negotiations to a successful end. Having been granted important economic concessions, the French government apparently now accepted the inclusion of the ECJ and Assembly among the institutions of the new communities as long as these did not gain any new competences and thus endangered the ratification of the treaties in the National Assembly. ${ }^{39}$ In the government, opposition to these institutional concessions was less entrenched than at the Quai d'Orsay, the officials of which were certainly not reknown for their European persuasion. At the same time the French government was under serious pressure from the five other governments to accept both the ECJ and Assembly. The establishment of a single ECJ and the maintenance of a unified legal system were considered of the utmost importance to ensure the coherence of the integration efforts. It would also be deeply problematic to create yet another court in a Europe that already had three -

38. A. BOEGER, The Background ..., op.cit.

39. M. Raymond Bousquet, Ambassadeur de France en Belgique à S.Ex. M. Christian Pineau; a.s. État actuel des travaux de la Conférence de Bruxelles sur la plan du Marché Commun, 10.12.1956, in: R. SCHULZE, T. HOEREN (eds.), Dokumente ..., op.cit., p.354-356. 
Schaus indeed warned that such a step would be particularly difficult to defend before the public of the Benelux countries. ${ }^{40}$

By December 1956, the groupe de rédaction that had been set up to draft the treaties, including the institutional clauses, could finally begin to work seriously on the ECJ. While, all of the major institutional questions were decided at the political level and by the heads of delegation, the Committee was given a relatively very free hand with regard to the ECJ. This surprising outcome of the negotiations was ensured by the close contacts of the Committee with the heads of delegation, in particular Snoy and Ophüls. Italian diplomat Roberto Ducci headed the committee which also included Nicola Catalano (l'Avvocatura dello Stato, Italy and later ECJ judge), Pierre Pescatore (Legal advisor, Foreign Ministry, Luxembourg and later ECJ judge), Yves Devadder (Legal advisor, Foreign Ministry, Belgium), Riphagen (Legal advisor, Foreign Ministry, Netherlands) Ernst Wohlfarth (German Ministry of Justice and later Director of the Legal Service of the Council), Josef Mühlenhöfer (Foreign Ministry) Hans-Peter von Meibom (Internal Ministry), Gaudet (Legal Service of the ECSC) and finally the two French representatives Vedel and Jean Jacques de Bresson (Legal advisor, Foreign Ministry, France). It is likely, as Pescatore writes in the fullest existing account of the work of the Committee, that all members except the French wanted to push as far as they possibly could in the direction of strong European institutions. Certainly, Catalano, Devadder, Gaudet, Pescatore and the German representatives would want to strengthen the constitutional features of the Court. The French representatives were the main adversaries of any such step. With Vedel absent for almost the entire period, it was the Gaullist-inclined Bresson who had to defend the minimalist position in the Committee. Only when the work was well under way did Vedel show up and, according to Pescatore's testimony, try to question the entire work of the committee. Ultimately Vedel's attempted coup had no effect on the outcome, however. ${ }^{41}$

While the work of the Committee with regard to the drafting of the EEC and the EURATOM Treaties has remained largely uncontroversial, its contributions to the ECJ and European law were consequential. Given the political constraints, the institutional position of the ECJ was maintained and thus its peculiar mix between an International Court and an Administrative Court was preserved. In some respects, the Committee even curbed the competences of the ECJ, negating the doctrinal developments of the 1950s. Thus, the widened access of private litigants that the ECJ had contributed to in its jurisprudence, was rolled back in a new article $173 .{ }^{42}$

40. A. BOEGER, The Background ..., op.cit.

41. P. PESCATORE, Les Travaux du "Groupe Juridique" dans la négociation des Traités de Rome, in: Studia Diplomatica, (XXXIV)1981, pp.159-178; Historical Archives of the European Union, Florence, Serie 09-Collection Melchionni/Ducci. INT. 63. 21.05/1984 Pierre Pescatore; Interview de Pierre Pescatore par Étienne Deschamps. Les personnalités marquantes des délégations nationales - 10.09.2003, www.cvce.lu

42. H. RASMUSSEN, Why is Article 173 (2) Interpreted against Private Plaintiffs, in: ELR, 5(1980), pp.112-127. 
Overall the Committee strengthened the ECJ's constitutional features, however. The most important novelty was the introduction of a system of preliminary references from national courts to the ECJ that went beyond the narrow one offered in article 41 of the Treaty of Paris. While article 41 had only given the ECSC ECJ the option to rule on the validity of acts, article 177 allowed the new Court to give its interpretation of European law. The proposal came from Catalano, who knew preliminary references from the Italian Constitutional system. It should be noted that article 177 was not an invitation to the ECJ to evaluate whether national law conflicted with European law. How to apply national law was explicitly beyond the jurisdiction of the Court, even if this was exactly how the article would eventually be used. Instead, article 177 was designed to make sure that the interpretation of European law was uniform throughout the Community. ${ }^{43}$ The enforcement of European law in the member states was on the contrary placed in article 169 and 170, which allowed the Commission and member states to bring infringement cases to the ECJ against those who infringed the treaty or secondary law. It is likely that very few in the committee actually had any notion of how the ECJ would eventually be able to use article 177. The German and Benelux representatives supported Catalano's proposal and Bresson eventually accepted what appeared to be a relatively weak legal instrument. ${ }^{44}$

Other important constitutional features were the principle in article 4 that the four main institutions of the Community should be considered equal, thus strenghtening the proto-federal nature of the Community. Likewise, article 189 streamlined the decision-making system of the ECSC (article 14 and 15 in the Treaty of Paris). Here the two main types of Community law essentially built on two diverse understandings of the nature of the Community. Council regulations (originally conceived as 'Community law', but renamed to avoid political trouble) were given direct effect inside the legal order of the member states. Council directives, by contrast, were framework decisions that required decisions by national parliaments and administrations to be enacted and thus worked along the lines of traditional international law. The ECJ would later undermine this distinction by granting those directives direct effect, which were formulated in a clear and detailed manner. The Committee also introduced a new emphasis on the concepts of legality (légalité) and responsibility (responsabilité). While article 164 of the EEC Treaty copied the Treaty of Paris article 32, in article 173 on the ECJ review of the legality of acts of the Council and the Commission, the notion of legality was strengthened. Similarly, the notion of responsibility of the Community institutions in the exercise of public power was strengthened in articles 183 and

43. The fear of how national judiciaries would interpret European law independently was especially strong with regard to the case of France, where it was the tradition that judges would follow orders from the Quai d'Orsay on questions of international law.

44. Bresson later claimed to have fought against the article. M. MANGENOT, Une Europe improbable. Les hauts fonctionnaires français dans la construction européenne 1948-1992, Dissertation, Université Robert Schuman de Strasbourg, 2000, pp.475-476. Unfortunately, there are no traces of Bresson and the work of the groupe de rédaction in the archives of the Quai d'Orsay. 
215. By emphasising principles, which were typical of a state, the difference between the Communities and other international organisations was made clear. ${ }^{45}$ Finally, the Committee did not invent the famous phrase from the preamble stating that the objective of the Treaty was 'an ever closer union among the peoples of Europe'. Although it reflected the same important thrust as some of the legal contributions of the Committee, this wording was added during a meeting between the heads of delegations on 16 and 17 February $1957 .{ }^{46}$

Considering how discreet were the changes in the status of the ECJ in the EEC Treaty, it should come as no surprise that the French Foreign Ministry found the institutional balance in the EEC Treaty satisfying. The Quai d'Orsay was, however, clearly mistaken in its assessment of the new ECJ as somewhat closer to the International Court of Justice in The Hague than the ECSC ECJ. ${ }^{47}$ The same was the case during the ratification of the Treaties of Rome in the national parliaments of the future member states. Nowhere was the question of the ECJ raised as a particular problem and the conclusion in general was that the institutional balance of the EEC had clearly tilted towards the member states. ${ }^{48}$

Even if understandable, this narrow conclusion about the relative unimportance of the ECJ and European law belied reality. Instead, the various attempts to build a European Constitution, including a Federal and Constitutional Court, as well as the establishment of the ECSC ECJ had led to several important results. Firstly, although European federalists were unsuccessful in securing a constitutional basis for European integration before 1954, federalist ideology spurred a particular legal thinking about the ECJ as having a constitutional nature and therefore constitutional tasks. This ideology provided a particular way of looking at the role of the ECJ and the European treaties, which would pave the way for legal activism by the new ECJ. Secondly, the battle over European constitutionalism from the late

45. P. PESCATORE, Les Travaux ..., op.cit., pp.159-178.

46. Whether it was Jean-François Deniau who came up with this line, as he later claimed, during the meeting is not possible to document. J.F. DENIAU, L'Europe Interdite, Éd. du Seuil, Paris, 1977, pp.64-65. Historical Archive of the Council of Ministers. HACM.NEGO.CM3.182, Groupe de Rédaction, Projet de réduction de préambule et des dispositions initiales du Traite instituant le Marche Commun, Bruxelles, 10.01.1957, MAE 62 f/57 ssw; HACM.NEGO.CM3.126, Comité des chefs de délégation, réunions des 16/17.2.1957, Projet d'ordre du jour, Bruxelles, 14.02.1957, Ch. Del. 322, Annexe, MAE 506 f/57 mr ; HACM.NEGO.CM3.126, Ausschuss der Delegationsleiter, Entwurf eines Protokolls über die Sitzung des Ausschusses der Delegationsleiter, 17. u. 18. Februar 1957 in Paris, Ch. Del. 356, MAE 613 d/57 arz/ls; HACM.NEGO.CM3.182, Groupe du Marché Commun, Projet de rédaction pour le préambule et les articles I A 3 et observations relatives à l'article 3 bis et à l'insertion d'une disposition unique concernant la politique économique générale ..., and HACM.NEGO.CM3.182, Comité des chefs de délégation, Projet de rédaction pour le préambule et les Articles 1 à 6 adoptée par le Comité des chefs de délégation le 16 février 1957, Bruxelles, 25.02.1957 Ch. Del. 352 (remplace le doc. Ch. Del. 533), MAE 586 (rev.) f/57 mts.

47. A. BOEGER, The Background ..., op.cit.

48. K.J. ALTER, Establishing the Supremacy of European Law - The Making of an International Rule of Law in Europe, Oxford University Press Inc., New York, 2001, p.183. 
1940s to 1954 and the establishment and practise of the ECJ led to the establishment of overlapping transnational networks of mainly jurists but also bureaucrats/politicians interested in European law. Finally, even if the ambitious plans for a European Constitution all failed, the ECJ and European law were given important constitutional features during the negotiations on the Treaty of Paris, through the ECJ jurisprudence before 1958 and finally through the work of the groupe de rédaction. Although, the political constraints were massive and the results limited, the influence of different federalist-inclined decision makers and jurists at different points of time made an important difference.

\section{The Legal Revolution}

In 1958 not even the most ardent supporter of a European Federation would have predicted that a legal revolution within half a decade would constitutionalize the Treaties of Rome and enhance the institutional status of the ECJ to that of a Constitutional Court in this newly emerging legal order. As we shall demonstrate below the work of the groupe de rédaction was not enough. What was also needed was an unusually activist ECJ.

We know relatively little about the positions of the judges of the ECJ before 1962 with regard to the question of constitutionalization. ${ }^{49}$ It is quite likely that only Delvaux and Lagrange were in favour of the notion of the ECJ as a potential Constitutional Court before 1958. To these was added Catalano after 1958..$^{50}$ However, it was only with the nomination of the French judge Robert Lecourt in 1962 that the balance inside the ECJ changed. A prominent figure in the Mouvement Républicain Populaire, Lecourt had during the 1950s been a firm supporter of the pro-European policies launched by Robert Schuman. He had been the leader of the Nouvelles Equipes Internationales and since 1955 a member of Monnet's Action Committee for the United States of Europe. Having been Ministre des Territoires d'Outre-Mer in the Debré government, he had left the government in August 1961 in protest at the Prime Minister's leadership style and his fellow party members had quickly followed him. ${ }^{51}$ His nomination as judge of the ECJ is shrouded in mystery. Apparently, de Gaulle had first approached Réne

49. The archive of the European Court of Justice is sealed off for the public indefinitely. Private archives are few and relatively poor, mainly due to the vow of secrecy sworn by judges of the ECJ.

50. See for example Catalano's view on the constitutional nature of the EC and the ECJ in 1963 in: Zehn Jahre Rechtsprechung des Gerichtshofs der Europäischen Gemeinschaften - Dix ans de jurisprudence de la cour de justice des communautés européennes, Carl Heymanns Verlag KG, Berlin-Bonn-München, 1965, pp.554-559.

51. P. PESCATORE, Robert Lecourt (1908-2004) - Eloge funèbre par Pierre Pescatore ancien Juge de la Cour, à l'audience solennelle du 7 mars 2005, in: Revue trimestrielle de droit européen, 3(2005), pp.589-796; N.-C. BRAUN, La Fonction Supranationale. Présidents - Membres - Juges des Communautés Européennes. Etude comparée des personnalités \& des collègues (1952-1967), dissertation, Fondation Nationale des Sc. Politiques, 1967, p.115. 
Cassin, ${ }^{52}$ but the ECJ had found him too old.$^{53}$ Instead, de Gaulle now nominated Lecourt who readily accepted the new challenge. ${ }^{54}$ The nomination remains inexplicable, but must be grounded in the intrigues of French domestic policy. At the same time it demonstrates the extent to which de Gaulle, if it was he who made the decision, remained ignorant about the legal dimension of European integration. ${ }^{55}$ Lecourt entered the court at the same time as the new Italian judge Alberto Trabucchi, who replaced a very disappointed Catalano. It is claimed that Trabucchi was nominated because his brother was Minister of Economy. As a lawyer of private law and a professor at the Universita' degli studi di Padova, he was a very unlikely choice for a position in the ECJ. Although not affiliated with any European federalist organisations, Trabucchi held views on the nature of European law similar to those of Catalano ${ }^{56}$ However serendipitous, the double change of personal would prove to be of vital importance. When the first serious test case on the nature of the EEC Treaty arose in 1962, the ECJ had turned activist.

The preliminary reference from the Dutch Administrative Court, the Tariefcommissie, asked whether article 12 of the EEC Treaty, which dictated a tariff standstill during the first phase of the transitional period, had direct effect. If this were the case, the Tariefcommissie wanted to know whether the Dutch law, based on a Benelux protocol, which had led to a rise of certain tariffs, would be in contradiction with European law. The preliminary reference from the Tariefcommissie clearly concerned the application of European law in a Dutch context, the second part of the question even explicitly asked about the validity of national law. ${ }^{57}$ Both topics were

52. Réne Cassin had been the legal advisor of the Free French government of Charles de Gaulle during the Second World War. From 1944 he was vice-president of the Conseil d'Etat and in 1960 he became a member of the Conseil Constitutionnel, which de Gaulle had established to control the judiciary in his new Fifth Republic. A.W.B. SIMPSON, Human Rights and the End of Empire, Britain and the Genesis of the European Convention, Oxford University Press, Oxford, 2001, p.365; M. MANGENOT, Une Europe improbable. Les hauts fonctionnaires français dans la construction européenne 1948-1992, Dissertation, Université Robert Schuman de Strasbourg, 2000, pp.465-466.

53. N.-C. BRAUN, La Fonction Supranationale..., op.cit., p.115. This information was later left out in the book: N.-C. BRAUN, Commissaires et juges dans les communautés européennes, Pichon et Durand-Auzias, Paris, 1972.

54. HAC.CEAB2.1137, Télex de Robert Lecourt, pour Monsieur M. Couve de Murville, Luxembourg le 18 mai 1962; HAC.CEAB2.1137, Télex de M. Couve de Murville à Monsieur Roger Reynaud, membre de la Haute Autorité, 17.05.1962.

55. Institut Charles de Gaulle, De Gaulle en son siècle, t.V, L'Europe, Plon, Paris, 1992, pp.115-120. Here Jean-Jacques de Bresson writes he never once heard de Gaulle mention the ECJ.

56. President Donner's welcome was also somewhat frosty. See Cour de Justice, Audiences solennelles 1959-1963, Library of the European Court of Justice, Luxembourg, pp.26-28. According to Giuseppe Perini the other judges quickly changed their mind with regard to Trabucchi's abilities. In G. PERINI, Alberto Trabucchi guirista europeo, unpublished dissertation, Universita' Degli Studi di Padova, 2005, pp.57-59. Interview with the référendaire of Catalano and Trabucchi, Paolo Gori in May 2008 confirmed the main outlines of the story, but he did not want to go into detail with the intrigues of Italian politics.

57. For the details of the case see HAC.BAC.371/1991.620, Note de Rey, (président du Groupe juridique) à Caron (président du groupe du marché intérieur). Objet: Observations de la Commission devant la Cour de Justice au sujet des demandes préjudicielles de la « Tarifcommissie » néerlandaise. 
arguably outside the jurisdiction of the ECJ which, according to article 177, was only allowed to give its interpretation of European law. This was also the argument advanced by the Dutch, Belgian and German governments that presented their views before the ECJ. ${ }^{58}$ The preliminary reference was they believed inadmissible. Moreover, all three states made clear that the EEC Treaty was one of international law and therefore article 12 could have no direct effect. ${ }^{59}$ The German position here is somewhat surprising, given the general stance by the German delegations during the negotiations on the Treaty of Paris and the Treaties of Rome. However, as Billy Davies documents in his article of this journal issue, it was a result of an administrative hiccup. ${ }^{60}$ The Advocate General, Karl Roemer, agreed with the three governments that the EEC Treaty was one of international law. As a consequence, the ECJ should avoid the temptation of widening its jurisprudence and rule that article 12 was an obligation directed to the member states governments and had no direct effect for citizens of those states. ${ }^{61}$

Taking this consensus on the nature of article 12 and the EEC Treaty into account, the Commission's position was arguably the most daring ever submitted before the ECJ. The Commission argued that unless private individuals were to be completely barred from access to the Court, the preliminary reference would have to be accepted. Besides, national courts were obliged to apply European law directly, even when this was in collision with a national law of a later date. As a consequence article 12 was self-executing and had a supreme status vis-à-vis national legislation. The Commission defended this radical view with the fact that the EC had a 'special character'. The EC had independent institutions with real powers, the legislation of which had direct effect on both member states and their citizens. Besides, the contracting parties had established a Court that had to ensure the effective and uniform application of European law throughout the Community. ${ }^{62}$

The Commission's position had been prepared by Gaudet and the legal service of the Commission. In a memorandum Gaudet had outlined three different paths that Community law could take depending on the judgment on Van Gend en Loos. The first two were essentially those of international law. This would mean that article 12 would have no direct effect and consequently the application of European law would depend completely on the good will of national governments,

58. HAC.BAC.371/1991.621, Stellungnahme der Regierung der Bundesrepublik Deutschland. E 2 1101 98; HAC.BAC.371/1991.621, Mémoire du gouvernement du Royaume des Pays-Bas. Affaire 26/62 - n. 71; HAC.BAC.371/1991.621, Mémoire de l'Etat belge. Réf. D. 123/E.L./N.126/ S.F.1.

59. Under traditional international law, direct effect could only be created if the contracting parties had clearly stated that this was their intention. This was a consequence of the famous Danzig ruling of the Permanent Court of Justice in 1928. E. STEIN, Lawyers ..., op.cit., op.cit., pp. 9-10.

60. See also B. DAVIES, The Constitutionalisation ..., op.cit.

61. HAC.BAC 371/1991.622, Rapport d'audience dans l'affaire 26/62.

62. HAC.BAC.371/1991.620, Mémoire de la Commission de la Communauté Economique Européenne. JUR/CEE/2750/62 - vdB/mb. og HAC.BAC.371/1991.622, Rapport d'audience dans l'affaire 26/62. 
administrations and parliaments. Instead Gaudet recommended a third option, which he termed a legal innovation, namely the establishment of a system where European law had direct effect and was supreme vis-à-vis national legislation. If the ECJ accepted the case and ruled that article 12 had direct effect this would also secure the legal rights of individuals who would be able to enforce European law before national courts and thus create a much needed alternative to the weak system of enforcement in article 169 and 170. The justification of this legal innovation could be found in several original features of the Community, which the member states had already accepted through their ratification of the Treaties. Gaudet admitted that direct effect and supremacy constituted two profound innovations with constitutional implications for several member states, particularly Germany and Italy neither of which granted supremacy to international law. But as Gaudet concluded: 'mieux vaut la surprise devant les exigences juridiques de la Communauté que le doute sur la signification même de la Communauté. ${ }^{63}$ In an untypical procedure for a Commission position in an ECJ case, the memorandum was presented to the whole Commission and at the $204^{\text {th }}$ meeting on 31 October 1962 the third radical option was adopted by Hallstein and his colleagues. ${ }^{64}$

Despite the leadership offered by the Commission, it was by no means certain how the ECJ would position itself. The rapporteur inside the ECJ, the Luxemburg judge, Léon Hammes, fell into line with Roemer and rejected the Commission's position. His view, supported by the Dutch President of the Court, André M. Donner, as well as the German judge, Otto Riese, was not to break with the elements of international law and instead emphasise the contractual nature of the EEC Treaty. It was in this situation that the new Italian judge Alberto Trabucchi wrote a memorandum opposing what seemed about to become the position of the Court. In the memorandum, which did not refer explicitly to the Commission's position, Trabucchi was concerned with the rights of individuals. The only way to give state citizens rights under European law would be to build the legal order on the special nature of the Community and give article 12 direct effect. The doctrinal consequences were significant and would raise constitutional problems for Germany and Italy. Therefore the ECJ should limit itself to introducing the doctrine of direct effect this time without raising the question of supremacy. ${ }^{65}$ Lecourt backed Trabucchi's intervention and together they convinced the two remaining judges Delvaux and the Italian Rino Rossi to back their doctrinal innovation. Lecourt probably found it easy to convince Delvaux with whom he had a shared past in the various transnational networks of Christian Democracy and who had

63. HAC.BAC.371/1991.620, Note à Rey et Caron. Objet: Observations de la Commission devant la Cour de Justice au sujet des demandes préjudicielles de la "Tariefcommissie" néerlandaise.

64. HAC.BAC.371/1991.620, Questions préjudicielles posées à la Court de Justice par la « Tariefcommissie » néerlandaise en vertu de l'article 177 - CEE (doc. S/06803/62). Projet de P.V. $204^{\mathrm{e}}$ réunion de la Commission.

65. Trabucchi's memorandum is included in G. PERINI, Alberto Trabucchi guirista europeo, unpublished dissertation, Universita' Degli Studi di Padova, 2005 with permission of the ECJ President, Rodriguez Iglesias. Giuseppe Perini, who is also the grandson of Alberto Trabucchi, has kindly made the document available. 
been positive about the notion of the ECJ as a potential Federal Court already in the 1950s. It was Trabucchi, who enlisted the support of Rossi. ${ }^{66}$

In the judgment the ECJ made clear that although article 177 did not concern the application of European law in the national context, it had the right to interpret all relevant points of European law in a preliminary preference even if these were implicit. Article 12 was given direct effect because the language constituted an unqualified, negative obligation. The wide interpretation of article 177 and the granting of direct effect to treaty articles that constituted clear obligations meant that the Court had turned the Treaties into a potential bill of rights for member state citizens. The Court justified this conclusion, which went against the normal requirements for the granting of direct effect for international law, with an interpretation of 'the spirit, the general scheme and the wording of the provisions' of the EEC Treaty. The argument was that the Community constituted a new legal order for the benefit of which the member states had limited their sovereign rights. Community institutions were independent and member state citizens were called upon to cooperate in the functioning of the Community through the European Parliament and the Economic and Social Committee. Furthermore, it was claimed that European law not only imposed obligations on member state citizens but was also intended to confer rights upon them. The existence of article 177 proved that the contracting parties had intended their national citizens to invoke European law before the national courts. This argumentation certainly built on a highly selective reading of the Treaty, but it also demonstrate how the constitutional elements in the EEC Treaty were decisive in the legal argument that lay behind the revolution of European law. ${ }^{67}$

If the Van Gend en Loos case was closely balanced inside the ECJ, the second step in the revolution of European law, the introduction of the supremacy of European law vis-à-vis national law, was legally so self evident that it did not cause the same controversy. The chance for the ECJ to take the second step came when an Italian Lower Court in Milan sent a preliminary reference to Luxembourg questioning whether a recent nationalisation law in the electricity sector was in breach of article 31 of the EEC Treaty. The Milan judge Vittorio Emanuel Fabbri had also send a preliminary reference to the Italian Constitutional Court which on 24 February 1964 ruled the nationalisation law constitutional on the principle that the latest law counts, lex posterior derogate priori. This amounted to an open challenge to European law, because it might potentially create an imbalance between those countries that gave supremacy to international law, and Italy and Germany that did not. The legal service of the Commission was quite clear in assessing this as a most serious threat that needed to be encountered both at the legal and political level. Eventually, it would take

66. Interview with Paolo Gori in May 2008.

67. Aff. 26/62 N. V. Algemene Transport - en Expeditie Onderneming van Gend \& Loos v. Nederlandse Administratie der Belastingen, (1963), Recueil 1963, p.0003. 
until the latter half of the 1970s for the Italian Constitutional Court to accept the supremacy of European law. ${ }^{68}$

In the court case, the Italian government, represented by Ricardo Monaco, not only found the preliminary reference inadmissible because it dealt with the application of European law, but also argued that a potential breach should be handled by the infringement procedure under article 169 and $170 .{ }^{69}$ The Commission presented its worries about the consequences of the Italian Constitutional Court judgment, thereby indirectly asking the ECJ to take a clear position on the problems of the relationship between national and European law caused by the doctrine of direct effect. ${ }^{70}$ It was Advocate General Maurice Lagrange who stole the show, however. The conclusion of his intervention was that the consequences would be disastrous if the lex posterior derogat principle was allowed to stand in Italy. In his view, the choice for member states upholding this principle was either to change their constitution or to leave the Community. While he did not want to characterise the EEC Treaty as either federalist or international, he pointed out that the Community was a genuine legal order distinct from the member states and characterised by transfers of competences to common institutions. The fact that certain Community decisions had direct effect, such as regulations and self-executing treaty articles (Van Gend en Loos), meant that a clash of competences between the European legal order and the national legal orders was inevitable. According to Lagrange transgressions by the Community institutions could be annulled or declared illegal through respectively article 173 and 184. However, when the member states' authorities acted beyond their competences there existed no similar system. This was a constitutional question that needed an appropriate solution. The supremacy of European law provided such a solution and was already established in France, the Netherlands, Luxembourg, and about to be in Belgium. Lagrange furthermore did not find an acceptance of supremacy by German and Italian courts insurmountable, in any case it was certainly required to safeguard the Community. ${ }^{71}$

The ECJ took its cue from the Commission and Lagrange and ruled that the preliminary reference was admissible. Even though the Commission found the Italian nationalisation law legal under European law, the doctrinal principle of supremacy was added. The ECJ controversially ruled that European law was supreme inside the national legal orders. This principle, the Court argued had already been accepted by the member states when they ratified the Treaties. Given

68. Costa c. E.n.e.1. \& Soc. Edisonvolta, Judgement n ${ }^{\circ 14,} 7$ March, 1964, 87 Foro Italiano 87, I, 465; A. STONE SWEET, The Judicial Construction of Europe, Oxford University Press, Oxford, 2005, pp.82-83.

69. HAC.BAC.371/1991.758, Rapport présenté conformément à l'art.18 du statut de la Cour de Justice des Communautés Européennes dans l'affaire 6/64.

70. Ibid.; and 805 HAC.BAC 371/1991, n758, Davanti alla Corte di Giustizia delle Comunità Europee, nel procedimento no. 6/64. JUR/CEE/1924/64 - I.

71. HAC.BAC 371/1991.758, Conclusions de M. l'Avocat général Maurice Lagrange dans l'affaire 6/ 64, prononcées à l'audience du 25 juin 1964. 
the silence of the EEC Treaty with regard to the principle of supremacy, the Court emphasised the special nature of the Community. It had 'unlimited duration', its own 'personality', 'legal capacity' and as well as 'real powers stemming from a limitation of sovereignty or transfer of powers from the states to the community'. If member states were allowed to replace European law with subsequent national law it would render article 189 that gave regulations direct effect meaningless, as well as result in an uneven application of European law giving rise to a discrimination on basis of nationality as prohibited by article $7 .{ }^{72}$ With this judgment, the ECJ had laid the corner stone for a new European legal order of a semi-federal character. The weakness of article 177 meant that the ECJ still needed to convince national courts to apply these doctrines, however. The gradual success of the ECJ in this respect is a story beyond the scope of this article. ${ }^{73}$

\section{Conclusion}

With the Van Gend en Loos and Costa vs ENEL judgement, the ECJ created the constitutional pillars, upon which it would base its ever-growing case law. Without the establishment of the principles of direct effect and supremacy and the widening of access for preliminary references under article 177, European law would have been much weaker and depended on the compliance of national governments, parliaments and administrations. The legal argument of the two judgments justified this with reference to the special nature of the Community and the legal order upon which it was based. In turn, the ECJ in a highly selective reading of the Treaties of Rome cited the general purpose of the Communities as well as several constitutional features to demonstrate the claimed special nature.

Did this interpretation come from the Commission as claimed by Eric Stein or was it, as argued by Hjalte Rasmussen, the invention of a federalist ECJ? In this article, we have demonstrated that the notion of the special nature of the Community had historical roots in the European federalism of the 1940s and 1950s and the prior development of the ECJ and European law in the context of the ECSC. Shaped by federalist ideology and the experience of the failure of attempts to base the European institutions on a Constitution, a particular legal thinking about the constitutional nature of the ECJ developed during the 1950s and was shared by a number of important actors in the field of European law. This was essentially the first version of the legal argument developed and refined by Gaudet in the legal service during the Van Gend en Loos case and later by the ECJ in the two judgments. But it was not a legal thinking without basis in the various Treaties that framed European integration from 1952 onwards. Indeed, the negotiations on the Treaty of Paris and the Treaties of Rome were influenced by negotiators and jurists,

72. Aff. 6/64 Flaminio Costa v. Enel, (1964), Recueil 1964, p.1194.

73. The most convincing study is K.J. ALTER, Establishing the Supremacy ..., op.cit. 
who wanted to promote the development of a Federal and Constitutional Court and furnish the Treaties with distinct constitutional features. These actors worked under serious political constraints and the progress they made during the above mentioned negotiations often seemed very small indeed. However, in the end they provided sufficient legal basis for the ECJ to revolutionise European law. The early history of the European legal order is thus one of federalist political and legal forces promoting, through different actors at different points in time, a particular constitutional thinking about the Treaties and the ECJ.

At the same time the legal revolution is clearly accidental. Without the bizarre nomination of Lecourt as judge of the ECJ, the balance inside the Court would have been different during the Van Gend en Loos and the judgment would most likely have refused to grant direct effect to article 12. Considering the importance of European law and the ECJ today, the nomination of Lecourt is arguably de Gaulle's most lasting contribution to European integration and one that went in completely the opposite direction to most of his European policies. 